ANDRZEJ MAJER

Uniwersytet Łódzki*

DOI: $10.26485 / \mathrm{PS} / 2017 / 66.2 / 4$

\title{
ODRODZENIE ŚREDNICH MIAST
}

\section{Streszczenie}

Przeobrażenia miast w drugiej połowie XX wieku i w wieku XXI można przedstawić za pomocą schematu triady urbanizacji, której pierwszy człon to miniony już kryzys miast, drugi to odnowa miast, a trzeci - odrodzenie. Odnowione wcześniej ośrodki miejskie wypełniają się stopniowo materialną tkanką nauki i kultury oraz miejscami twórczej aktywności ludzi. Problematyka średnich miast stanowi lukę w naukowym rozumieniu całokształtu aktualnych zagadnień miejskich. Miasta średnie rozumiane są tu jako stosunkowo duże ośrodki miejskie liczące poniżej 1 mln mieszkańców (wyróżnienie opiera się więc zarówno na kryterium liczebności populacji, jaki i funkcjonalnym).

Empiryczne wskaźniki świadczą o pozytywnym trendzie „odrodzenia,” które dostrzegalne jest w rosnącym zaludnieniu i w postaci zmian ilości, struktury i jakości sieci sklepów, salonów usługowych, lokali rozrywkowych i gastronomicznych służących popularnej kulturze. W aglomeracjach Ameryki i Europy mających za sobą kuracje „odnowy” zrewitalizowana przestrzeń i społeczno-kulturalne atrybuty nowej miejskości znów pociągają amatorów. Tendencje te zaczynają być także widoczne w miastach postsocjalistycznych w krajach Europy Środkowo-Wschodniej, w tym także Polski.

Słowa kluczowe: triada urbanizacji, rewitalizacja, odrodzenie miast

Opracowanie to stara się przedstawić główne aspekty warunkujące sytuację współczesnych miast i wskazać (w sposób ograniczony ze względu na objętość tekstu) mechanizmy prorozwojowe lub hamujące rozwój średnich miast, funkcjonujących w różnych kontekstach i w zróżnicowanych uwarunkowaniach polityki krajowej i lokalnej. Na tym tle tekst zwraca uwagę na fakt, że mniejsze

* Prof., Instytut Socjologii; e-mail: amajer@lodz.home.pl 
pod względem liczby ludności i powierzchni miasta, w tym także postindustrialne ośrodki niebędące wielkimi metropoliami, mają współcześnie, w dobie globalizacji szansę na pomyślną koniunkturę ze względu na potrzeby harmonizowania i równoważenia rozwoju.

\section{TRIADA FAZ WSPÓŁCZESNEJ URBANIZACJI}

Nauki społeczne traktują miasta jako miejsca skupiania się największej liczby problemów gospodarczych i społecznych. Prawie wszystko, co ważne dla życia i rozwoju społeczeństw od początku istnienia miast zawsze ogniskowało się właśnie w nich; dotyczy to zwłaszcza dużych miast - postrzeganych przez pryzmat najtrudniejszych kwestii społecznych, jako ośrodki skupienia osadnictwa w największym stopniu doświadczające trudności i skutków bezrobocia, wykluczenia społecznego i fizycznej degradacji zabudowy. Wśród gęstej i różnorodnej populacji duża, nierzadko drastyczna skala upadku przemysłu i dekoncentracji aktywności gospodarczej wywoływała napięcia w wielu społecznościach miejskich i stwarzała skomplikowane wyzwania dla władz miejskich. Nic dziwnego, że badacze miast podzielali raczej pesymistyczny pogląd na temat perspektyw rozwojowych miast, a dyskurs wokół miast jeszcze do niedawna był zdominowany przez pojęcia kryzysu i upadku [np. Hall, Hay 1980; van den Berg 1982; Begg i in. 1986]. Niektórzy analitycy skłonni byli nawet traktować miasta jako anachroniczne pozostałości epoki przemysłowej, biorąc pod uwage wysokie koszty transportu i niską mobilność siły roboczej, które kiedyś wynikały z tego, , że łańcuchy dostaw były bardziej lokalne, a ludzie żyli blisko miejsc, gdzie pracowali. Wiele faktów potwierdzało złożoność stanu nazywanego ogólnie „postindustrializacją".

Literatura teoretyczna wyróżnia trzy główne rodzaje miast świata [Hall 2001]. Pierwszy z nich charakteryzuje się żywiołowym i nadmiernym wzrostem w stosunku do możliwości zapewnienia mieszkańcom godziwych warunków życia. To megamiasta, na przykład w Afryce na południe od Sahary, w Indiach, na Bliskim Wschodzie oraz w uboższych regionach Ameryki Łacińskiej. Poziom biedy jest w nich równie wysoki jak tempo wzrostu wskutek nieustannej migracji z obszarów wiejskich i wysokich wskaźników urodzeń. Drugi rodzaj to miasta o równie dynamicznej strukturze wzrostu, ale w krajach o wyższych dochodach ludności - w Afryce Wschodniej, w Ameryce Południowej, na Karaibach i na Bliskim Wschodzie. Populacja tych miast nie rośnie tak gwałtownie, a presja demograficzna i ekologiczna w wyniku ich rozwoju nie jest tak silna i pozostawia 
przestrzeń dla wzrostu potencjału gospodarczego. Trzeci rodzaj stanowią wielkie i mniejsze miasta Ameryki Północnej, Europy, Azji i Australii. One także przeżywają trudności, chociaż zupełnie innego rodzaju: największym problemami były w nich, lub są nadal, nie wzrost, a demograficzny regres i starzenie się ludności, podobnie jak w społeczeństwach, których są częścią. Peter Hall i Ulrich Pfeiffer utrzymują, że ponieważ są to społeczeństwa i miasta stosunkowo zamożne, mają zdolność renowacji swojej infrastruktury i łagodzenia w rozmaity sposób negatywnych skutków regresu [Hall, Pfeiffer 2000]. Opracowanie to skupia się dalej na trzecim z wyróżnionych rodzajów, a więc praktycznie dotyczy miast europejskich i amerykańskich, i zwraca uwagę na przejawy regeneracji - odrodzenia.

Postindustrialna ewolucja skierowała społeczeństwa w stronę etapu nazwanego Nową Ekonomią (Nową Gospodarka). Ta umowna nazwa wysuwa na pierwszy plan autonomiczność produkcji opartej na najnowszej wiedzy, dostępnej przede wszystkim naukowym i kulturalnym elitom wiodących państw świata. Wśród przewodnich motywów ewolucji ku Nowej Ekonomii na czołowych miejscach znalazły się kreatywność i kultura, jako cechy społeczeństw, miast i jednostek. Tym razem jednak - w przeciwieństwie do poprzednich faz, kiedy to rola liderów zastrzeżona była dla wybranych miast-węzłów sieci lub miast globalnych - ta faza i jej główne mechanizmy sprawcze mogą w rzeczywistości objąć większość miast, z których prawie każde dysponuje większym lub mniejszym potencjałem rozwoju; należy tylko ów potencjał zidentyfikować i umiejętnie wykorzystać. Dotyczy to również ludzi nazwanych nową klasą metropolitalną lub klasą kreatywną (według Richarda Floridy) czy członkami neoplemion (jak określił jch Michel Maffesoli), świadomych swoich praw do miasta - sięgając do tytułu nowej książki Davida Harveya. Te uniwersalne zmiany dopiero się zakorzeniają, w dodatku w nierównym stopniu: jedne społeczeństwa mogą być bardziej zainteresowane eksponowaniem kreatywności i kultury, inne mniej. Ewolucjonistyczny punkt widzenia zakłada, że te drugie i tak będą musiały przejść drogę przebytą przez te pierwsze.

Stadialne przeobrażenia miast $\mathrm{w}$ drugiej połowie $\mathrm{XX}$ wieku można zobrazować za pomocą schematu triady rozwojowej urbanizacji. Pierwszy człon tej triady to kryzys miast. W połowie zeszłego wieku aglomeracje miejskie, w szczególności koncentrujące różne gałęzie przemysłu uznawanego za szczytowe osiagnięcia postępu i kultury materialnej, pod wpływem obiektywnych i strukturalnych czynników dotknęło załamanie koniunktury gospodarczej i redukcja miejsc pracy - podstawy egzystencji części mieszkańców. Infrastrukturę $i$ atrybuty nowoczesnego standardu życia: wygodę, łatwość przemieszczania się, obfitość usług, bliskość miejsc pracy, zaczęto przenosić poza duże miasta wraz 
z narastającą falą suburbanizacji. Najbardziej pożądanym środowiskiem zamieszkania stały się dalekie przedmieścia lub osiedla obrzeżne - w przeciwieństwie do miast, a szczególnie ich centralnych dzielnic, będących synonimami kryzysu, komunalnego zaniedbania i patologii.

Drugi człon triady urbanizacji to odnowa miast, stanowiąca reakcję systemów społecznych na kryzys, a zatem będąca przeciwieństwem i przeciwdziałaniem jego skutkom. Przez całą drugą połowę XX wieku, a w wielu wypadkach także obecnie, równolegle podejmowano wysiłki mające na celu odwrócenie degradacji i przywrócenie do życia miejskich struktur ekonomicznych i społecznych; okazało się to również przełomowe dla wypracowania kierunków całej polityki społecznej.

Trzeci człon triady to odrodzenie miast. Różnica w stosunku do poprzedniego stadium jest nieco łatwiejsza do dostrzeżenia w kategoriach demograficznych, trudniej natomiast precyzować ją w kategoriach funkcjonalno-przestrzennych. Polega na tym, że odnowione i ożywione wcześniej, dzięki wielu nowym inwestycjom i przedsięwzięciom inwestycyjnym o różnych rozmiarach, miasta (dodajmy: w których udało się niejako zaspokoić najpilniejsze potrzeby w dziedzinie infrastruktury komunalnej) wypełniają się stopniowo materialną tkanką nauki i kultury oraz miejscami twórczej aktywności ludzi; w ten sposób miasta odradzają się, wzbogacają i zabiegają o miano „kreatywnych”. Ujmując to lapidarnie, w stadium odnowy względną przewagę miały pilniejsze przekształcenia użytkowej tkanki miast, natomiast po ich realizacji, już w fazie odrodzenia miast na pierwszy plan wysuwają się elementy niematerialne i materialne o znacznie mniejszej skali, bardziej symboliczne, znaczące i komunikujące.

Współistnienie coraz większej liczby instytucji i usług służących szeroko pojętym sferom kultury i nauki oraz konsumpcji może świadczyć o tym, że miasta są atrakcyjnym środowiskiem życia. W jednych funkcjonuje i daje już pomyślne rezultaty, w innych dopiero powstaje samonapędzający się mechanizm: nowoczesne gospodarki rozwijają się szybciej i bardziej efektywnie dzięki koncentracji instytucji wytwarzających wiedzę oraz kreatywności ludzi wykształconych, o wysokich kwalifikacjach i umiejętnościach, odznaczających się inwencją w myśleniu i działaniu. Mechanizm ten tworzy struktury przestrzenne częściowo spontanicznie, częściowo natomiast pod wpływem oddziaływań zachodzących między nowymi i dziedziczonymi elementami całego układu. To stanowi główną bazę kapitału kreatywnego i porusza twórcze przemysły, te z kolei są kluczowymi elementami potencjału rozwojowego i stymulatorami zmian wpływających na atrakcyjność miast jako miejsc zamieszkania, pracy i inwestowania. 
Odnowę miast potwierdzały lub potwierdzają nadal, jak ma to miejsce obecnie w wielu polskich miastach, duże inwestycje strukturalne i przekształcenia urbanistycznej tkanki miast, służące podniesieniu jakości życia zbiorowości mieszkańców. Faza odrodzenia wyraża się w mniejszej skali jako szereg drobniejszych projektów mających, obok materialnego wymiaru, także znaczenie kulturalne - symboliczne lub komunikujące.

W Europie na opisywane tu przemiany decydujący wpływ miały wydarzenia historyczne ostatnich dziesięcioleci ubiegłego stulecia, które zasadniczo zmieniły jej polityczno-ekonomiczną mapę. W następstwie integracji Unii Europejskiej do postaci jednolitego rynku i traktatu z Maastricht państwa narodowe nie sąjuż oddzielnymi terytoriami, ale formują względnie jednolity system przestrzenny, ułatwiający przepływ ludzi, towarów i informacji. Przystappienie krajów dawnego obozu socjalistycznego do Unii i ekonomiczne oraz kulturalne otwarcie Europy Wschodniej spowodowało, że cały kontynent stał się częścią globalnego systemu wymiany. Przemiany te wpłynęły zasadniczo na sytuację miast, wiążąc je coraz ściślej ze względnie zunifikowanym systemem miejskim całego kontynentu. Zanikające granice i nowe sieci transportowe tworzą nieznane przedtem możliwości gospodarczego rozwoju. Dawne regionalne monopole są zagrożone przez globalną, międzynarodową konkurencję, ale w zamian za to gospodarka (w tym również miasta) mogą korzystać z nowych, rozległych rynków.

Współczesne nauki zajmujące się w różny sposób miastami, a więc np. geografia humanistyczna, socjologia miasta, miejska antropologia kulturowa oraz wybrane nurty w ramach innych subdyscyplin nauk społecznych, w ciagu ostatnich dekad zdominowały koncepcje światowych systemów i perspektywa globalizacji. Wysunęło to na pierwszy plan globalne ośrodki metropolitalne (miasta globalne), ze zrozumiałych względów skupiające uwagę badaczy, a naukowe studia empiryczne ukazywały rosnącą koncentrację ekonomicznej, politycznej i kulturowej energii w tych wiodących miastach świata. Ośrodkami rozwoju stały się głównie miasta centralne w poszczególnych krajach, absorbujące największy potencjał ludnościowy, będące koronnymi rynkami pracy i miejscami operowania coraz znaczniejszymi zasobami kapitałowymi różnego rodzaju. Zlokalizowanie głównego zasobu nowoczesnej produkcji i władzy w największych miastach wręcz skłaniało do przekonania, że mniejsze miasta są zaledwie biernymi odbiorcami procesów czy zjawisk pochodzących ze szczytu wytworzonej w ten sposób hierarchii i że doświadczenia ludzi w nich żyjących zasługują na znacznie mniejsze zainteresowanie. 


\section{ŚREDNIE MIASTA}

W drugiej połowie XX wieku stopniowo na gruncie nauk społecznych do głosu zaczęło dochodzić także przekonanie, że świat nie jest strukturą zintegrowaną i poddaną wpływowi jednego, wszechogarniającego procesu. Immanuel Wallerstein pisał o coraz wyraźniejszym podziale światowego systemu na dominujące obszary centralne, semiperyferyjne i peryferyjne [Wallerstein 1979]. Wybitna badaczka globalizacji Saskia Sassen opisywała nową geografię miejsc centralnych i marginalnych [Sassen 2001]. Większość badaczy miast była zgodna co do tego, że efektem transferu i dyspersji produkcji w wymiarze globalnym były głębokie, niekorzystne zmiany na rynku pracy tradycyjnych centrów przemysłowych oraz pogłębianie się dezindustrializacji - zanikanie przemysłu jako głównej bazy ekonomicznej.

Także badania empiryczne [Storper 1999] zaczęły dowodzić, że globalizacja nie jest jedynym, a w każdym razie nie decydującym czynnikiem rozwoju. Z perspektywy kilkudziesięciu minionych lat wiemy, że zmieniła ona w znacznej mierze świat; na przykład dzięki kooperacyjnym związkom towary czy usługi są wytwarzane i użytkowane w niezależnych od siebie, dobrze skomunikowanych częściach globu. Czy jednak ma to dla ludzi w wielu krajach realne znaczenie? Teza głosząca, że procesy globalizacji zmieniają także społeczną strukturę i wpływają na życie ludzi w każdym niemal zakątku planety, należy raczej do sfery mitologii, choć oczywiście przekonanie o ewolucyjnym oddziaływaniu globalizacji potwierdza się w wielu dziedzinach; przykładowo: łatwiejszy przepływ wiedzy, idei i umiejętności ułatwił rozwój mass mediów. Równolegle z kolejnymi fazami rewolucji informacyjnej pojawiały się zmiany przybliżające stan globalnego połączenia, czego oczywistym przykładem jest Internet. Postępuje integracja i rozszerzają się kontakty, z jednej strony między przedsiębiorstwami o charakterze lokalnym i globalnym, z drugiej - instytucjami ponadnarodowymi i globalnymi. Nieporozumieniem byłoby jednak przyjmować za pewnik, że procesy te włączają także osobiste biografie, w sposób racjonalny i pożądany albo niechciany, do sieci globalnych związków i integracji społeczeństw, gospodarek czy kultur lub też, że przyczynia się to znacząco do rozpowszechnienia albo wprowadzania w życie ideałów społeczeństwa obywatelskiego.

W tym kontekście wątpliwości może budzić zwracanie większej uwagi na problematykę globalizacji i globalnych (światowych) miast. Analiza doświadczeń wielkich metropolii przesłania w ten sposób równie ważną rzeczywistość mniejszych i mniej centralnych miejsc, nazwanych w tym tekście miastami średnimi (średniej wielkości). Nie jest łatwo zdefiniować tę dominującą liczebnie grupe 
miast . W polskim piśmiennictwie geograficznym, - pisze Anna Runge - pojęcie miasta średniej wielkości nie jest jednoznaczne - w większości przypadków podaje się przedział od 20 tys. do 100 tys. mieszkańców jako charakterystyczny dla tej grupy ośrodków miejskich [Runge 2012]. Klaus Kundman za „średnie” uznaje miasto liczące od 20 tys. do 200 tys. mieszkańców, w zależności od gęstości zaludnienia i systemu urbanistycznego danego kraju [Kunstmann 2010]. Z kolei według źródeł amerykańskich każde miasto o liczbie mieszkańców od 100 tys. do 300 tys., znajdujące się w ramach obszaru statystycznego metropolitalnego liczącego co najmniej $1 \mathrm{mln}$ osób, mogłoby kwalifikować się do miast średniej wielkości [Markusen, Lee, DiGiovanna 1999]. Miasta średnie nazywane się też niekiedy miastami drugorzędnymi - domyślnie: w stosunku do odgrywających pierwszorzędną rolę stolic danych krajów [Second tier cities matter 2016].

Ten krótki przegląd wskazuje na niejednoznaczność definicyjna. W niniejszym artykule miasta średnie rozumiane są jako stosunkowo duże ośrodki miejskie, liczące poniżej $1 \mathrm{mln}$ mieszkańców, których przykładami mogą być Manchester i Glasgow w Wielkiej Brytanii czy Kraków i Łódź w Polsce. Pod uwagę są więc brane zarówno kryteria liczebności populacji, jak i funkcjonalne. W przeciwieństwie do większości analiz poświęconych czynnikom prorozwojowym we wiodących ośrodkach metropolitalnych studia nad mniejszymi miastami, zwłaszcza peryferyjnymi, w odniesieniu do największych skupisk miast postprzemysłowych, stanowią istotny brak w literaturze przedmiotu. Tymczasem przesunięcie perspektywy widzenia całej problematyki miejskiej od zasadniczo pesymistycznego oglądu do pozytywnej wiary w ich potencjał opiera się na innym niż przedtem założeniu: ośrodki miejskie, niezależnie od ich wielkości, są ludziom niezbędne jako miejsca do życia, zwłaszcza jeśli występuje w nich szereg udogodnień. Bliskość i wzajemna dostępność ludzi czy instytucji były i nadal są istotnym warunkiem rozwijania form wymiany, interakcji i współzależności. To właśnie - pisze Allen Scott - stanowi siłę życiową miasta. Poszukiwanie lub też korzystanie z wzajemnej bliskości wykorzystywane jest w wielu rozmaitych formach ekonomicznej lub społecznej działalności w wybranych punktach miejskiej struktury, ale szczególnie intensywnie tam, gdzie mają one wysoką gęstość i częstotliwość, to jest wokół lub w samym centrum miast [Scott 2008].

Globalizacja i inne unifikujące procesy powodują, że większość ekonomicznych i społeczno-kulturowych przejawów miejskiego życia przebiega jednakowo lub w zbliżony sposób we wszystkich miastach, bez względu na ich wielkość. Nie ma jednak powodu, aby tezą o uniwersalnym podobieństwie przebiegu i skutkach współczesnej urbanizacji [Jakóbczyk-Gryszkiewicz 2012], a zwłaszcza 
o możliwościach odradzania się miast postindustrialnych, nie objąć także miast mniejszych, także postindustrialnych lub o cechach peryferyjności.

Zaniedbanie problematyki średnich miast stanowi lukę w rozumieniu całokształtu aktualnej problematyki miejskiej, szczególnie w świetle bieżących tendencji demograficznych. Bardziej niż kiedykolwiek przedtem pożądany byłby zrównoważony rozwój osadnictwa, sprzyjający włączeniu wszystkich zasobów i prawidłowemu zarządzaniu zmianami demograficznymi, mieszkalnictwem, mobilnościa, przechodzeniem na odnawialne źródła energii; wszystko to w kontekście demograficznego starzenia się społeczeństw. Miasta średniej wielkości funkcjonują niemal na równi z największymi jako węzły rozwoju i mają duży wkład w lokalny, regionalny, krajowy i europejski wzrost gospodarczy. Istnieją dowody, że bardziej równomierna dystrybucja inwestycji w poszczególnych krajach oraz lepsze wyniki gospodarcze w ,miastach drugiego rzędu” prowadzą do prawidłowego, policentrycznego rozwoju europejskiej tkanki miejskiej [Second tier cities matter 2016]. Już w 2000 roku znaczna część miejskiej populacji świata mieszkała w miastach zajmujących drugo- lub trzeciorzędną pozycję w hierarchii regionalnych i krajowych systemów miejskich. Statystyki geograficzno-urbanistyczne pokazują, że Europejczycy zamieszkują głównie miasta średniej wielkości, z populacjami liczącymi od 250 tys. do $5 \mathrm{mln}$, a prawie połowa ludności świata żyje w miastach liczących niecały milion mieszkańców [The state of European cities 2016].

Liczba osób mieszkających w miastach liczących między 500 tys. a $1 \mathrm{mln}$ mieszkańców może zwiększać się w podobnym tempie, rosnąc od 363 mln w 2014 roku do 509 mln w roku 2030. W 2014 roku blisko połowa ludności miejskiej na świecie żyła w ośrodkach miejskich liczących mniej niż 500 tys. mieszkańców. Przewiduje się, że do 2030 roku mniejsze miasta nadal będą domem dla około 45\% mieszkańców terenów zurbanizowanych. Odsetek ludności zamieszkującej średnie i małe miasta różni się znacznie w skali regionów świata: dotyczy to największej liczby, bo blisko dwóch trzecich, mieszkańców Europy, połowy liczby mieszkańców miast Afryki i tylko jednej trzeciej ludności miast Ameryki Północnej [wszystkie dane za: World Urbanization Prospects: The 2014 Revision].

Według powszechnych, bardziej oficjalnych definicji za miasta średnie lub drugiego rzędu [The City 2002] uważa się obszary ulokowane poza głównymi obszarami metropolitalnymi, przy czym pojęcia mniejszych rozmiarów regionu, miasta lub peryferyjności łączą się zwykle z pojęciami dystansu, odmienności, zależności; pod względem rzeczowym zbliżone jest to do charakterystyki peryferyjności. To rozumienie uwypukla czynniki o charakterze przestrzennym - niekorzystne położenie geograficzne, odległość od regionów centralnych. Mniejszy lub peryferyjny region czy ośrodek miejski traktowane sąjako obszary 
charakteryzujące się zespołem niekorzystnych cech w porównaniu z regionami centralnymi. Może je cechować wysokie bezrobocie, względne ubożenie ludności i jej odpływ, niska produktywność, niska dostępność terytorialna. Potrzeba aktywizacji tych obszarów wynika z polityki spójności Unii Europejskiej oraz względów społecznych, ekologicznych, takich jak choćby przeciwdziałanie nadmiernej koncentracji zasobów w obszarach metropolitalnych i ekonomicznych, zwłaszcza ograniczanie migracji, gdyż obejmuje ona osoby lepiej wykształcone i przedsiębiorcze, a więc utrwala bariery rozwoju [Krajowa Strategia Rozwoju Regionalnego... 2010]. Pojawia się zatem pytanie o czynniki aktywizacji obszarów peryferyjnych i potrzeba przyjrzenia się współczesnej historii miast poza centralnymi metropoliami.

Mniejsze regiony czy miasta cechuje z reguły mało zróżnicowana struktura produkcyjna, $z$ dużym udziałem produkcji tradycyjnej, pracochłonnej, narażonej na konkurencję z krajów o niższych kosztach produkcji. Obszary peryferyjne charakteryzują się niedostatecznym rozwojem sektora badawczo-rozwojowego oraz niskim poziomem innowacyjności. Rozwój odbywa się zwykle poprzez adaptowanie nowych czynników z regionów centrum. Tworzy się w ten sposób relacja zależności między obszarami centrum a peryferiami o wyraźnie jednokierunkowym charakterze; innymi słowy, relacje między obszarami metropolitalnymi i pozametropolitalnymi mogą być interpretowane jako przypadek relacji rdzeń (centrum) - peryferie. Różne poglądy na na ten temat są formułowane zwłaszcza na gruncie geografii, przeważa jednak przekonanie, że szybki rozwój regionów stanowiących rdzeń odbywa się kosztem regionów peryferyjnych i pogłębia ich zależność od rdzenia. Istotną rolę w negatywnym oddziaływaniu rozwoju rdzenia na pogłębienie peryferyjności innych regionów odgrywają efekty wymywania, polegające na drenażu wykwalifikowanej kadry, kapitału i innych zasobów, na co zwraca uwagę Bolesław Domański [Domański 2010].

Od początku lat 80 . XX wieku obserwujemy jednak narastającą zwolna tendencję odchodzenia od traktowania „mniejszości” jako rozmiaru czy „peryferyjności”, wyłącznie w zawężającym kontekście. Kwestia ta zaczyna być analizowana wieloaspektowo; zmieniają się tym samym kryteria klasyfikacji stanu i sytuacji miast. Już nie jeden decydujący czynnik odległości geograficznej odgrywa w tych analizach główną rolę, ale liczne elementy, w tym zwłaszcza jakościowe, na przykład: poziom życia, kapitał społeczny i kulturowy, czy bardziej nawet szczegółowe, np. średnia długość życia lub dostęp do nowych technologii. Oznacza to, że w przypadku oceny, czy dany region należy traktować jako peryferyjny, trzeba przyjąć względnie szeroki wachlarz wskaźników, które pozwolą na ocenę jego relatywnej słabości lub odwrotnie - siły. Konieczne jest również 
stosowanie adekwatnej metodologii, łączącej aspekty ilościowe i jakościowe, co pozwala na szersze i bardziej zróżnicowane oceny stopnia zaawansowania lub zacofania danego miasta, jego gospodarki i zbiorowości - również w stosunku do pozostałych krajów, regionów i miast ujętych w analizie. Problem peryferyjności jest zagadnieniem wieloaspektowym i w takim kontekście powinien być dyskutowany.

Punktem odniesienia dla takiego ujęcia może być geograficzny, czterofazowy model relacji centrum-peryferie opracowany przez Johna Friedmanna [1986]. Ostatnia z wyróżnianych przez niego faz, odpowiadająca czasom współczesnym, opisuje stopniowe wyrównywanie się dysproporcji, a integracja przestrzenna gospodarki pomaga $\mathrm{w}$ osiaggnięciu równowagi - jednego ze skutków przeciwdziałania negatywnemu wpływowi globalizacji. Według Friedmanna w dłuższym czasie może zachodzić rozprzestrzenianie się rdzenia (metropolii o znacznie skoncentrowanych zasobach) na regiony peryferyjne dzięki przepływowi innowacji i kapitału. W rezultacie może dojść do stopniowej integracji i wyeliminowania dualizmu rdzenia i peryferii oraz wykształcenia bardziej zrównoważonej struktury przestrzennej.

To z gruntu optymistyczne przekonanie stoi, póki co, w sprzeczności z poglądami wielu uczonych, w tym także polskich. Jałowiecki [2007] akcentuje, że metropolie są silniej powiązane ze sobą niż z otaczającym je zapleczem. Następuje osłabienie lub zerwanie związków gospodarczych metropolii z jej regionalnym zapleczem, które staje się metropoliom funkcjonalnie niepotrzebne [Gorzelak, Jałowiecki 2001]. Uniezależnienie się metropolii od ich regionalnego zaplecza występuje zwłaszcza w gospodarce informacyjnej. Rozprzestrzenianie się metropolii jest słabe i ma ograniczony zasięg, przeważają efekty wymywania (eksploatacji) otaczających je obszarów. Prowadzi to do marginalizacji przyległych regionów, a różnice między metropoliąjako centrum i peryferiami ulegają pogłębieniu [Smętkowski 2007].

Cechami nowej gospodarki są: elastyczna specjalizacja produkcji, integracja dostaw, produkcji i dystrybucji, wzrost zatrudnienia w sektorze usług, a w szczególności szybkie reagowanie na rosnącą selektywność, różnorodność i zmienność preferencji konsumentów i ich pluralistyczno-indywidualistycznych systemów wartości lub stylów życia. Wymagania nowej gospodarki prowadzą także do nowych wzorów lokalizacji, jej tradycyjne ograniczenia zanikają. Nowe, nazywane „miękkimi” czynniki lokalizacyjne, takie jak dostępność usług biznesowych w sąsiedztwie, obecność instytucji badawczo-rozwojowych, obfitość wykwalifikowanej siły roboczej, dobre zaplecze edukacyjne, atrakcyjne środowisko naturalne, korzystny wizerunek regionu, dobry klimat dla biznesu i konsekwentni lokalni 
przywódcy, stają się coraz bardziej istotne. Nie ma kontrowersji co do tego, że są to główne czynniki kształtujące obecnie urbanizację w Europie.

Jaka jest zatem na tym tle sytuacja średnich (w tym peryferyjnych) miast, a zwłaszcza, jak wygląda ona na obszarze państw zmuszonych do pozostawania przez dziesięciolecia na marginesie głównego nurtu rozwoju kapitalizmu? Istnieje szereg studiów próbujących analizować i wyjaśniać w sposób kompleksowy ogólne cechy dawniej socjalistycznych miast $\mathrm{i}$ ich transformację w miasta postsocjalistyczne [Szelenyi 1996; Enyedi 1998; Steinführer 2004]. Oprócz tych swoistych kompendiów opublikowano wiele badań w czasopismach lub materiałach konferencyjnych [Musil 1993; Sykora 2000]. Najczęściej ich autorami byli uczeni od wielu lat badający miasta w krajach socjalistycznych. Istnieje również pewna liczba monografii zajmujących się przekształceniami miejskimi w poszczególnych krajach postsocjalistycznych, wybranymi miastami albo różnymi aspektami tych przemian, na przykład mieszkaniami, zarządzaniem, urbanistyką itp. [Bodnár, Molnar 2010; Sýkora 1999].

Analitycy miast w Europie Środkowo-Wschodniej i Wschodniej byli w większości w pełni świadomi faktu, że rozwój obszarów miejskich i regionów w poszczególnych krajach postsocjalistycznych różnił się dość znacznie od analogicznych procesów w Europie Zachodniej, między innymi z powodu odziedziczonego z historii przestrzennego rozkładu różnych struktur miejskich i regionalnych w poszczególnych krajach, różnych okresów trwania i opresyjności rządów komunistycznych, ale także ze względu na różne podejścia ideologiczne do miast (co uwidaczniała szczególnie różnica między ośrodkami miejskimi byłego ZSRR i ,nowych” krajów socjalistycznych).

Europa Środkowa i Wschodnia zapoczątkowała w 1989 roku burzliwy okres demontażu aparatu państwowego socjalizmu i transformacji na rzecz systemu gospodarki rynkowej, czemu towarzyszyły gwałtowny regres gospodarczy i rosnące nierówności. Jednak już na przełomie tysiącleci niemal wszystkie gospodarki wschodnioeuropejskie wykazywały ponowne ożywienie, a do 2005 roku zdołano przywrócić poprzedni poziom produkcji krajowej lub wdrożono mechanizmy pozwalające na doganianie liderów. Jednym z przejawów tego ożywienia był boom budowlany napędzany przez rosnące ceny nieruchomości i inwestycje spekulacyjne [Badyina, Golubchikov 2005; Fawkes 2007]. Stanowił on jeden z czynników, które przyczyniły się nie tylko do poszerzenia wielkości miast, ale umożliwiły nawet wprowadzenie ich do różnych światowych list rankingowych i tabel [Taylor i in. 2011]. Moskwa, Sankt Petersburg, Kijów, Bratysława, Praga, 
Warszawa, Lublana, Tallin, Budapeszt, Bukareszt, Ryga, Sofia i Wilno w ostatnim okresie pojawiły się wśród bogatszych i droższych miast.

Alison Stenning i Kathrin Hörschelmann kwestionują marginalizowanie doświadczeń świata niezachodniego w dyskursie o współczesnej gospodarce czy powszechności globalizacji. Opowiadają się wprawdzie za perspektywą akcentowania postsocjalistycznych różnic między Wschodem i Zachodem, jednak uznają, że nie powinno to przysłaniać podobieństw tendencji rozwojowych, w szczególności sprzeciwiają się ich rozważaniu w kategoriach postkolonializmu, jaki-zdaniem niektórych badaczy - zajmuje miejsce postsocjalizmu [Stenning, Hörschelmann 2008]. Przemysł, w poprzednich warunkach mający stałe oparcie w państwie, zaczął działać na zmienionych zasadach gospodarki kapitalistycznej. Te jego gałęzie, które nie potrafiły w odpowiednim czasie i stosownie do nowych wymogów, stać się konkurencyjne, upadały. Stosunkowo szybko nastapiło jednak odrodzenie. Zamykane fabryki często na powrót stawały się miejscami pracy lub powstawały nowe fabryki, najczęściej będące oddziałami koncernów z zachodniej części kontynentu. Było to możliwe dzięki względnej taniości siły roboczej, ale także wysokim i elastycznym kwalifikacjom.

W wielu publikacjach z dziedziny nauk o miastach Europa Środkowo-Wschodnia przedstawiana jest jako hybrydowy typ rozwoju obszarów miejskich lub wręcz jako szczególny przypadek zapóźnienia pod wieloma względami. To niesłuszny punkt widzenia - stwierdzają dobitnie Annette Steinführer i Annegret Haase - ponieważ zarówno społeczeństwa, jak i miasta centralnego i wschodniego regionu europejskiego stoją obecnie w obliczu tych samych problemów, jakich doświadczają kraje w Europie Zachodniej. Starzenie się społeczeństw, spadek rozrodczości, zmniejszanie się udziału młodych grup wiekowych w strukturze ludności przy wydłużaniu się przeciętnej trwania życia świadczą wyraźnie o działaniu Drugiego Przejścia Demograficznego; są to zjawiska charakteryzujące duże miasta i obszary metropolitalne Europy i Ameryki Północnej już od końca lat 60. ubiegłego wieku. Konsekwencje zmian demograficznych stanowią jedno z głównych wyzwań także w krajach Europy Środkowej i Wschodniej i będą miały również negatywny wpływ na rozwój miast, ich strukturę i rynek mieszkaniowy, podobnie jak ma to miejsce w Europie Zachodniej [Steinführer, Haase 2008].

W krajach Europy Środkowej i Wschodniej dokonało się potrójne przejście: od socjalizmu do kapitalizmu, od gospodarki centralnie sterowanej do wolnego rynku (wraz z konkurencją na tym rynku i w handlu, prywatyzacją przemysłu, deregulacją rynków nieruchomości i zmianą polityk społecznych) oraz od względnej autarkii w ramach systemu wzajemnego wspierania państw socjalistycznych 
do konkurencyjnego pozycjonowania w globalnym systemie gospodarczym. Jak ujmują to Sasha Tsenkova i Zorica Nedovic-Budić, to potrójne przejście było głównym motorem zmian mających implikacje w układach przestrzennych: (1) zmian gospodarczych (globalizacja, dezindustrializacja, spadek produkcji przemysłowej), (2) zmian społecznych (,przejście demograficzne," polaryzacja dochodów, rozszerzenie się ubóstwa) oraz (3) zmian miejskich systemów zarządzania (nowe relacje administracji centralnej i lokalnej, świadczenie usług, planowanie przestrzenne i urbanistyka). Autorki zwracają także uwagę na trzy rodzaje zmian przestrzennych w postsocjalistycznych miastach, mianowicie pojawienie się nowych obszarów produkcji i konsumpcji, jako odzwierciedlenie globalizacji i restrukturyzacji gospodarczej w ramach hierarchii miast; zróżnicowania społeczne i stratyfikację osiedli mieszkalnych, rosnące nierówności i występowanie oaz dobrobytu obok enklaw ubóstwa; konflikty przestrzenne na tle selektywnego rozwoju miast, nowych modeli zarządzania i zmiany instytucjonalnej. Ważnym fragmentem transformacji była „cicha rewolucja” w postaci decentralizacji władzy do poziomu samorządów, która znacząco wpłynęła na wydajność miast postsocjalistycznych. Dynamikę miejskich przemian w ujęciu przestrzennym wzmagały zupełnie nowe reguły gospodarki gruntami i tworzenie się obrotu nieruchomościami [Tsenkova, Nedovic-Budić 2006]. Sekwencja i rytm tych zmian przekształca systemy miejskie, zmienia społeczno-demograficzny skład dzielnic i prowadzi do wykształcania się nowych miejskich stylów życia.

Autorzy porównawczych badań europejskich trendów miejskich traktujący kontynent jako jedność [m.in. Hall, Hay 1980; van den Berg i in. 1982] już w latach 80 . XX wieku pokazywali, że we wschodnioeuropejskich krajach socjalistycznych, mimo wszelkich różnic w porównaniu z Europą Zachodnią, występowały podobne zjawiska. Porównywalny był sekwencyjny model rozwoju przemysłu w miastach i bariery tego rozwoju. Wbrew wszelkim odmiennościom nie różniły się zbytnio mechanizmy dostępu do przestrzeni, ilustrujące podobne modele lokalizacji i przemysłowej decentralizacji (ukazywali to Paul Cheshire i Stephen Sheppard [1995]). Co ważniejsze, identyfikowano trzy wspólne, główne etapy urbanizacji: najpierw koncentrację przestrzenną, następnie suburbanizację (decentralizację i spadek zaludnienia w mieście centralnym) i ostatecznie dezurbanizację (rozproszenia osadnictwa i działalności gospodarczej do satelitarnych miast i obszarów wiejskich). Rzecz jasna, podobieństwa nasiliły się jeszcze po zmianie ustroju ekonomicznego. Wspólnym dla całej grupy krajów Europy Środkowej i Wschodniej zjawiskiem, podobnie jak dla reszty krajów europej- 
skich i Ameryki, był także kryzys miast, mający jednak inne uwarunkowania niż w krajach rozwiniętego Zachodu.

Procesy odnawiania, mające nierzadko charakter znacznych interwencji w struktury przestrzenne, zdradzają wiele cech żywiołowości o charakterze egzogennym oraz dokonujących się wskutek oddziaływania sił zewnętrznych w jednym czasie. Działa naraz kilka czynników: migracje ludności, dyfuzja kulturowa, wszechwładza masowej kultury i mediów. Często dochodzi do spontanicznego i bezrefleksyjnego powielania wzorów, a o dynamice tego procesu decyduje nasilona mobilność i intensywność kontaktów, zderzona z dotychczasowymi normami i wartościami, siłą tradycji, poziomem infrastruktury. Pod wpływem uniwersalnych praw kapitalizmu również w warunkach miast Europy Środkowej i Wschodniej dochodzi do polaryzacji form osadnictwa, choć niekoniecznie na wzór amerykański. Można prognozować, przy uwzględnieniu efektu opóźnienia i modyfikacji przez lokalne warunki, że w przestrzeni tych miast utrwalą się i zapewne jeszcze rozszerzą obszary ubóstwa. Raz utracone funkcje przemysłowe nie wszędzie i nie od razu mogą być zastąpione innymi funkcjami. Na „porzuconych” obszarach bardzo szybko dochodziło do fizycznej degradacji zabudowy, wzrostu bezrobocia, pogorszenia jakości infrastruktury, koncentracji patologii i ubóstwa.

\section{ODRODZENIE MIAST: NOWA PERSPEKTYWA}

Splot opisywanych wyżej czynników zmian nie zatrzymał rozwoju miejskiego. Przeciwnie, odkąd wiele aspektów osiaggnęło punkt krytyczny, można było obserwować pojawianie się punktów zwrotnych. Nie znaczy to, że problemy związane z niedawnym kryzysem lub trwającą odnową wielu miast zmniejszyły się. Mimo to empiryczne wskaźniki sugerują pozytywny trend, nazwany w tym opracowaniu symbolicznie „odrodzeniem” lub - jak określali to Anne Power i inni - „odradzaniem się miast niczym Feniks z popiołów” [Power, Ploeger, Winkler 2010].

Perspektywa definiowania tego nowego stanu miast, nazwanego „odrodzeniem" miejskim, jest w pierwszym rzędzie antynomią powszechnych jeszcze w drugiej połowie XX wieku tez o „kryzysie” miast. Percepcja miast, zwłaszcza poprzemysłowych, jako zdominowanych przez nierozwiązywalne problemy ekonomiczne, patologie społeczne czy fizyczną degradację, zmieniła się pod wpływem faktów. Rządy i samorządy oraz organizacje gospodarcze skłonne są obecnie widzieć te miasta raczej jako miejsca potencjalnego ekonomicznego dynamizmu i przewidywać korzyści płynące z ich fizycznego i kulturalnego odnawiania. Jeszcze $\mathrm{w}$ trakcie debaty nad upadkiem miast $\mathrm{w}$ rozwiniętych gospo- 
darkach zaczęto dostrzegać zapowiedzi przeciwnej tendencji, czyli odradzania się opartego na dwóch rodzajach czynników - ekonomicznych i demograficznych. Obecnie te czynniki wzmocniły się i utrwaliły, co upoważnia do ostrożnego optymizmu co do przyszłości regionów miejskich. W ciągu ostatnich dziesięcioleci $\mathrm{w}$ wielu regionach miejskich dokonało się już przejście od gospodarki produkcji przemysłowej do usługowej, w szczególności usług wiedzochłonnych, skojarzonych z wysokim popytem na interakcje face-to-face. Jak udowodnił to Sven Illeris, udział usług jest na ogół większy w dużych regionach miejskich niż w regionach mniejszych lub pozamiejskich [Illeris 2009: 113-134]. Zwiększone dochody i wysoki poziom edukacji przełożyły się na wzrost popytu na usługi i udogodnienia podnoszące komfort życia w miastach, począwszy od coraz bogatszej oferty sklepów po wyszukane restauracje i awangardowe teatry.

Biorąc pod uwagę podobny charakter tych zjawisk, można wymienić kilka przyczyn oraz płaszczyzn odradzania się miast. W uproszczeniu dadzą się one podzielić na ekonomiczno-demograficzne i społeczno-kulturowe. Mówiąc o pierwszych, należy zauważyć, że nawet powolne przyrosty liczby ludności mają pozytywny wpływ na całość miejskich wyników ekonomicznych. Istnieją dowody na to, że sama wielkość populacji i gęsto zaludnione, lokalne rynki pracy w aglomeracjach miejskich mogą sprzyjać zwiększaniu się produktywności miejskiej gospodarki jako całości [Scott, Storper 2003]. Jak pokazują badania Ivana Turoka i Vlada Mykhnienki, trajektoria sytuacji ekonomiczno-społecznej europejskich miast ma tendencję wznoszącą z powodu koncentracji w tych miastach demograficznych i gospodarczych, endogennych czynników uruchamiających rozwój. Innymi słowy, dużym miastom z powodu obfitej i zróżnicowanej podaży zawodów nie może grozić ekonomiczna zapaść (wyjątkiem od tej reguły jest oparte na monokulturze produkcji samochodów amerykańskie Detroit), a przynajmniej są one w stanie skutecznie jej zapobiegać ze względu na większą skalę gospodarczych i społecznych możliwości, wyposażenie w placówki naukowe (uniwersytety, instytuty, laboratoria badawcze), instytucje kulturalne, korzystny wpływ szybszego obiegu informacji, rozwiniętą łączność i międzynarodowe powiązania oraz wiele innych aktywów. Miasta w gospodarczym i politycznym centrum Europy, gdzie bliskość wiodących ośrodków koncentracji kapitału, władzy, biznesu i innowacji technologicznych jest największa, rozwijają się szybciej i lepiej niż miasta ulokowane na peryferiach. Nieco wyraźniejsze ożywienie staje się udziałem miast, w których są lepsze warunki życia, na przykład panuje słoneczny lub łagodny klimat. Trzeba też dodać, że miasta zachodnioeuropejskie wykazują więcej oznak ożywienia, ponieważ nie pozostawały w tyle ani nie doświadczały skutków głębokich zmian politycznych i ekonomicznych, jak 
miasta położone na wschodzie kontynentu, gdzie przed ponad dwudziestu laty miała miejsce brzemienna w skutki transformacja ku gospodarce kapitalistycznej.

Do przyczyn ekonomiczno-demograficznych należą korzystne efekty zewnętrzne grupowania się firm należących do sektora kreatywnej gospodarki i przemysłów kultury. Przyczyną niedawnego jeszcze trendu wyprowadzania działalności ekonomicznej poza miasta była łatwość pozyskania nowych terenów lub moda na funkcjonowanie w warunkach „ekologicznej poprawności”. Obecna faza rozwojowa, nazywana kapitalizmem poznawczo-kulturalnym [Scott 2008], pozbawiła znaczenia wiele czynników lokalizacji i na pierwszy plan wysunęły się korzyści skupiania się firm w zbiory, klastry czy inne formy terytorialnej koncentracji. Przestrzenne zgrupowanie pozwala firmom dzielić koszty funkcjonowania, a przez to skupiać się bardziej na podstawowej działalności i częściowo uniezależniać od pomocniczych usług. Zaletą koncentracji jest też szybszy przepływ informacji, powodujący wzrost potencjału innowacyjnego. Bliskość jest ważna ze względu na ułatwienia w komunikacji i możliwość dzielenia skomplikowanych projektów między firmami, centrami badawczymi i powiązanymi organizacjami [Storper i Manville 2006; Scott 2006].

Definicje i sposób pojmowania odrodzenia miast różnią się w zależności od branych pod uwagę kryteriów. Jak pisze Paul C. Cheshire, proces ten wciąż trudno jest określić, chociaż potwierdzają go liczne dowody [Cheshire 2006]. Wybitni badacze tego zjawiska w Europie, Ivan Turok i Vlad Mykhnenko, rozumieją je następująco: „Określamy odrodzenie się w prosty sposób jako niż demograficzny, po którym nastapił okres przyrostu ludności" [Turok, Mykhnienko 2007: 165-182]. Ann Markusen i Greg Schrock definiują odrodzenie w kategoriach ożywiania się gospodarki miejskiej i przez pryzmat zwiększonej aktywności środowisk artystycznych. Według nich odrodzenie ma wiele odmian i jego oznaki można znaleźć w różnych miastach o rozmaitych cechach [Markusen, Schrock 2006]. Sako Musterd sugeruje, że odrodzenie jest samorzutnym skutkiem konkurowania z innymi ośrodkami miejskimi o pozyskiwanie inwestycji i turystów. Taka rywalizacja zmusza wszystkie ośrodki miejskie do starań; odrodzenie ma miejsce wówczas, gdy dane miasto w wyniku współzawodnictwa otwiera nowe lub rozwija istniejące formy i staje się dzięki temu coraz bardziej atrakcyjnym miejscem [Musterd 2006]. Według Michaela Storpera i Michaela Manville’a bieżący etap rozwoju obszarów metropolitalnych pozwala zaobserwować dwie tendencje. Pierwsza dotyczy ponownego „ożywiania się”, w znaczeniu demograficznym i ekonomicznym, aglomeracji, z których jeszcze nie tak dawno „wyprowadzał się” przemysł i które systematycznie opuszczali mieszkańcy. Drugą tendencją jest wyraźne ożywianie się centrów miast, odzyskujących atrakcyjność i wypełniających 
się coraz obficiej małym lub średnim biznesem kulturalnym, gastronomicznym i rozrywkowym służącym urozmaiceniu życia i pobudzającym aktywność klasy kreatywnej [Storper, Manville 2006].

Jak dotąd brak dostatecznego zasobu wyników badań potwierdzających analogiczne tendencje w miastach Europy Środkowej, w tym Polski, mimo to można już wyróżnić płaszczyzny obiektywizowania się tego procesu. Najłatwiej dostrzegalna jest zmiana ilości, struktury i jakości sieci sklepów, salonów usługowych, lokali rozrywkowych i gastronomicznych służących kulturze popularnej; w większości wypadków jest to spontaniczne wyjście naprzeciw rosnącemu popytowi na usługi alternatywne lub niezależne. Te nazwy próbują definiować nietypową infrastrukturę komercyjną i usługi z dziedziny nietradycyjnej kultury, począwszy od galerii niszowej sztuki czy rzemiosła artystycznego do baru przekąskowego tapas. Często te niezależne usługi zgrupowane są w ciagi, pasaże lub galerie; większość z nich czerpie korzyści ze wspólnej lokalizacji i łączy różne rodzaje działalności i świadczonych usług, np. café baru i księgarni, nierzadko będąc miejscami środowiskowych spotkań członków grup mniejszościowych czy hobbystycznych. Przykładami takiej alternatywnej działalności może być warszawski kompleks kulturalno-edukacyjny Centrum Artystyczne Fabryka Trzciny powstały w 2003 r., oferujący różnorodne rodzaje aktywności artystycznej, m.in. spektakle teatralne, wystawy, festiwale, koncerty, wykłady i debaty. Inny przykład to jedna z głównych atrakcji Łodzi: zgrupowanie kilkudziesięciu butików z unikatową lub alternatywną modą, nietypowych lokali gastronomicznych (łączących na przykład wypiek pieczywa na miejscu ze sprzedażą prostych dań), specjalistycznych księgarni, piwnic winnych i wielu innych miejsc, mieszczących się w celowo pozostawionym w pierwotnym stanie wielkim kompleksie pofabrycznym w samym centrum, nazwanym w sposób znaczący dla wtajemniczonych - Off-Piotrkowska.

Druga płaszczyzna to rosnące i wymierne w kategoriach zysków z obrotu nimi znaczenie podmiotów z dziedziny nauki czy kultury i ich rola na arenie lokalnej i międzynarodowej. Polityka miejska niekiedy jest zorientowana na przebudowę miast w taki sposób, aby planować przestrzeń dla usług alternatywnych, co potencjalnie może sprzyjać integracji mieszkańców i budowaniu konkurencyjnej przewagi wobec innych miast.

Proces odtwarzania się w miastach, przede wszystkim w centrach ośrodków miejskich (chociaż powierzchnia czy liczba ludności nie są w tym wypadku decydującym kryterium), sprzyjających warunków pracy i życia nie następuje szybko, mimo to daje widoczne efekty. Jak można szacunkowo obliczyć, wartość dóbr i usług wyższego rzędu, w tym kulturalnych, wytwarzanych obecnie 
w miastach potroiła się w stosunku do wartości sprzed 25 lat. Europejskie miasta - piszą Ivan Turok i Vlad Mykhnienko - są najwyraźniej znacznie bardziej zaawansowane pod względem czystej ilości wytwarzanej w nich, coraz bardziej opłacalnej, produkcji, niż były wcześniej. Począwszy od 1980 r., przybyło w nich $20 \%$ miejsc pracy; zarazem rynki zatrudnienia są obecnie wyraźniej zróżnicowane i podlegają cyklicznym wahaniom (do 1994 r. był zauważalny wzrost w skali całej Europy, po którym nastapił trwający do dzisiaj powolny spadek). Autorzy ci są ostrożni w ocenie przyrostu zaludnienia miast europejskich; ich zdaniem obecny stan bardziej adekwatnie określałby termin „wolny, stały wzrost". Średnio oznacza to przyrost liczby ludności na poziomie 10\% w stosunku do 1980 r. Stosunkowo najwolniejsze (licząc od r. 1985) jest tempo ogólnego demograficznego i przestrzennego rozwoju miast w Niemczech, Grecji, Austrii, Portugalii i Holandii (danych dla Europy Wschodniej brak). Mykhnienko i Turok obliczyli, że pośród 25 badanych miast różnej wielkości w latach 1985-2005 kilka mniejszych odstawało na niekorzyść od średniej (na przykład Tampere i Turku w Finlandii, Luton w Wielkiej Brytanii, Bolonia i Triest we Włoszech). Na drugim krańcu spektrum znalazły się miasta o wyższym tempie rozwoju, jak Sztokholm w Szwecji czy Bristol i Edynburg w Anglii [Turok, Mykhnienko 2008]. Duże miasta Hiszpanii: Barcelona, Madryt i Walencja zarejestrowały największy wzrost populacji w ciągu ostatniego dziesięciolecia; na przykład zaludnienie Barcelony zwiększyło się o 150 tys., Sevilla i Bilbao także nieco powiększyły swoje zaludnienie.

Po drugiej stronie Atlantyku, w Stanach Zjednoczonych, analogiczne dane, uzupełnione dodatkowo o przegląd cen na rynku nieruchomości, świadczą o podobnych zjawiskach. Proces nazwany niekiedy przesadnie back-to-the-city movement („ruchem powrotu do miast”) ilustrować może fakt, że w latach 1990-2000 trzy największe miasta USA, a więc Nowy Jork, Los Angeles i Chicago, odnotowały wzrost liczby ludności na poziomie odpowiednio 9\%, 6\% i 4\%. W latach 2000-2010 ludność stołecznego Waszyngtonu zwiększyła się o 5,2\% [Lesthaege, López-Gay 2013].

Jeszcze na początku drugiej połowy XX w. miasta w rozwiniętym ekonomicznie świecie kurczyły się ludnościowo. Klasę średnią wypychała z nich nieodparta moda na dom w przestrzeni suburbiów, a jeszcze bardziej dyskomfort życia, szczególnie brak bezpieczeństwa w miastach. Obecnie jednak w aglomeracjach Ameryki i Europy, zwłaszcza mających już za sobą kuracje „odnowy”, zrewitalizowana przestrzeń i społeczno-kulturalne atrybuty nowej miejskości znów pociagają. Badacze zmian zachodzących w miastach są zgodni co do tego, że nastąpiła inwersja - odwrócenie się trendów depopulacji i ucieczki średniej 
klasy na przedmieścia, a za nią kres wyprowadzania się handlu, gastronomii czy rozrywki.

Do społeczno-kulturowych przyczyn odrodzenia należą aspekty opisywane między innymi przez Richarda Floridę i Charlesa Landry (głównie, choć nie wyłącznie w odniesieniu do dużych metropolii): miasta z natury skupiają kulturalną witalność, bogatą infrastrukturę społeczną i konsumpcyjne udogodnienia szeroki wybór miejsc zakupów i rozrywki, tworzących potencjał pozwalający na odnoszenie korzyści z gospodarki opartej na wiedzy [Florida 2010; Landry 2013]. Można powiedzieć - za Stanisławem W. Kłopotem i Mateuszem Błaszczykiem - że w miastach tych (podobnie jak we współczesnych społeczeństwach w ogóle) konsumpcja traktowana jest jako swoisty, nadrzędny cel, któremu podporządkowane są społeczne normy, obyczajowość, polityka czy nawet etyka [Kłopot, Błaszczyk i in. 2010]. Takie miasta zachęcają w naturalny sposób do osiedlania się ludzi utalentowanych w wielu dziedzinach nauki i kultury. Wszyscy korzystają z frapującej atmosfery bohemy - budowanej przez inspirujące się wzajemnie środowiska, pomagające w tworzeniu współcześnie rozumianej przewagi konkurencyjnej [Storper, Manville 2006].

Prawie tak długo jak istnieją miasta mamy do czynienia z prognozami ich upadku. Od niedawna pojawiają się także naukowe przepowiednie ich odrodzenia. Te drugie zdają się dzisiaj urzeczywistniać. Duże miasta mogą być miejscami odnowionego dynamizmu gospodarczego i akceleratorami dobrobytu narodowego, dlatego warto przypatrywać się nieco bliżej wyjątkowemu momentowi ich odradzania się.

\section{BIBLIOGRAFIA}

Badyina Anna, Oleg Golubchikov. 2005. "Gentrification in central Moscow - a market process or a deliberate policy? Money, power and people in housing regeneration in Ostozhenka". Geografiska Annaler: Series B, Human Geography 87(2): 113-129.

Bayliss Darrin. 2007. "The rise of the creative city. Culture and creativity in Copenhagen". European Planning Studies 15(7): 889-903.

Begg Iain, Barry Moore, John Rhodes. 1986. Economic and social change in urban Britain and the inner cities. In: Critical issues in urban economic development, Volume 1, V.A. Hausner (eds.), 10-49. Oxford: Oxford University Press.

Bodnar Judit, Virag Molnar. 2009. "Reconfiguring private and public. State, capital and new housing developments in Berlin and Budapest". Urban Studies 7: 789-812.

Cheshire Paul C. 2006. "Resurgent cities, urban myths and policy hubris. What we need to know". Urban Studies 43(8): 1231-1246.

Cheshire Paul C., Stephen Sheppard. 1995. "On the price of land and the value of amenities". Economica 62: 247-267. 
Domański Bolesław. 2010. Kapitał zagraniczny a rozwój polskich regionów. W: Przekształcenia struktur regionalnych. Aspekty społeczne, ekonomiczne i przyrodnicze, S. Ciok, P. Migoń (red.), 263-274. Wrocław: Uniwersytet Wrocławski, Instytut Geografii i Rozwoju Regionalnego.

Dziemianowicz Wojciech. 1997. Kapitat zagraniczny a rozwój regionalny i lokalny w Polsce. Studia Regionalne i Lokalne 54. Warszawa: Uniwersytet Warszawski, Europejski Instytut Rozwoju Lokalnego i Regionalnego.

Enyedi György. 1998. Transformation in Central European post-socialist cities. In: Social change and urban restructuring in Central Europe, G. Enyedi (eds.), 9-34. Budapest: Akademia Kiado.

Florida Richard. 2010. Narodziny klasy kreatywnej oraz jej wplyw na przeobrażenia w charakterze pracy, wypoczynku, społeczeństwa i życia codziennego. Warszawa: Narodowe Centrum Kultury. tłum. T. Krzyżanowski, M. Penkala.

Friedmann John. 1966. Regional development policy. A case study of Venezuela. Cambridge, Mass.: MIT Press.

Friedmann John. 1986. "The world city hypothesis". Development and Change 17: 69-83.

Giddens Anthony. 2002. Nowoczesność i tożsamość. „Ja” i spoleczeństwo w epoce późnej nowoczesności. Warszawa: Wydawnictwo Naukowe PWN.

Gorzelak Grzegorz, Bohdan Jałowiecki. 2001. „Strategie rozwoju regionalnego województw. Próba oceny". Studia Regionalne i Lokalne 1(5): 41-59.

Hall Peter. 2001. Cities in civilization. New York: Fromm International.

Hall Peter, Dennis Hay. 1980. Growth centers in the European urban system. London: Heinemann.

Hall Peter, Ulrich Pfeiffer. 2000. Urban future 21. A global agenda for twenty-first century cities. London: Federal Ministry of Transport, Building and Housing of the Republic of Germany.

Illeris Sven. 2009. "Services and regional development". Journal of Urban and Regional Analysis 1(1): 3-15.

Jałowiecki Bohdan. 2007. Globalny świat metropolii. Warszawa: Wydawnictwo Naukowe SCHOLAR.

Kabisch Nadja, Dagmar Haase. 2011. "Diversifying European agglomerations. Evidence of urban population trends for the 21st century". Population, Space and Place 17(3): 236-253.

Kabisch Nadja, Dagmar Haase, Annegret Haase. 2012. "Urban population development in Europe, 1991-2008. The examples of Poland and the UK". International Journal of Urban and Regional Research 36(6): 1326-1348.

Kłopot Stanisław W., Mateusz Błaszczyk, Jacek Sutryk, Pawel Trojanowski, Jacek Pluta. 2010. Studia nad strategia rozwoju społecznego miasta Wrocławia. Warszawa: Wydawnictwo Naukowe Scholar.

Krajowa Strategia Rozwoju Regionalnego 2010-2020. 2010. Warszawa: Ministerstwo Infrastruktury i Rozwoju.

Kunzmann Klaus R. 2010. Medium-sized towns, strategic planning and creative governance. In: Making strategies in spatial planning. Knowledge and values, M.C. Grazia, V. Monno (eds.), 27-45. Vienna: Springer International Publishing AG.

Landry Charles. 2013. Kreatywne miasto. Warszawa: Narodowe Centrum Kultury.

Lesthaeghe Ron, Antonio Lopez-Gay. 2013. "Spatial continuities and discontinuities in two successive demographic transitions". Demographic Research 28(4): 77-136. 
Markusen Ann R., Yong-Sook Lee, Sean DiGiovanna. 1999. Second tier cities. Rapid growth beyond the metropolis. Minneapolis: University of Minnesota Press.

Markusen Ann, Greg Schrock. 2006. "The artistic dividend. Urban artistic specialisation and economic development implications". Urban Studies 43(10): 1661-1686.

Musil Jiři. 1993. "Changing urban systems in post-communist societies in Central Europe. Analysis and prediction". Urban Studies 30(6): 899-905.

Musterd Sako. 2006. "Segregation, urban space and the resurgent city". Urban Studies 43(8): $1325-1340$.

Mykhnenko Vlad, Ivan Turok. 2008. "East European cities. Patterns of growth and decline, 1960-2005". International Planning Studies 13(4) (November): 311-342.

Pacione Michael. (red.). 2002. The city. Critical concepts in the social sciences. London: Routledge.

Power Anne, Jörg Ploeger, Astrid Winkler. 2010. Phoenix cities. The fall and rise of great industrial cities. Bristol: Policy Press.

Scott Allen J., Michael Storper. 2003. "Regions, globalization, development". Regional Studies 37(6-7): 579-593.

Scott Allen J. 2008. „Inside the city. On urbanisation, public policy and planning”. Urban Studies 45(4): 755-772.

Scott Allen J. 2008. "Resurgent metropolis. Economy, society and urbanization in an interconnected world". International Journal of Urban and Regional Research 32(3): 548-564.

Second tier cities matter. 2016. ESPON EGTC.

Smętkowski Maciej. 2007. Delimitacja obszarów metropolitalnych - nowe spojrzenie. W: Rozwój, region, przestrzeń, G. Gorzelak, A. Tucholska (red.), 215-233. Warszawa: Ministerstwo Rozwoju Regionalnego.

Steinführer Annett. 2004. "The urban transition of inner-city areas reconsidered (a German-Czech comparison)". Moravian Geographical Reports 14(1): 3-16.

Steinführer Annett, Annegret Haase. 2007. „Demographic change as a future challenge for cities in East Central Europe". Geographica Annales 89(2): 183-195.

Stenning Alison, Kathrin Hörschelmann. 2008. "History, geography and difference in the post-socialist world: or, do we still need post-socialism?”. Antipode 40(2): 312-335.

Storper Michael. 1999. Globalization, localization and trade. In: A handbook of economic geography, G. Clark, M. Feldman, M. Gertler (eds.), 1-28. Oxford: Oxford University Press.

Storper Michael, Michael Manville. 2006. "Behaviour, preferences and cities. Urban theory and urban resurgence". Urban Studies 43(7): 1247 -1274.

Sýkora Ludĕk. 2005. Suburbanizace a jeji sociální, ekonomické a ekologické di̊sledky. Praha: Ústav pro ekopolitiku, o.p.s.

Szelényi Ivan. 1996. Cities under socialism - and after. In: Cities after socialism: urban and regional change and conflict in post-socialist societies, G. Andrusz, M. Harloe, I. Szelenyi (eds.), 286-317. Oxford: Blackwell.

Taylor Peter J., Ben Derudder, Michael Hoyler, Kathy Pain, Frank Witlox. 2011. European cities in globalization. In: Global urban analysis. A survey of cities in globalization, P.J. Taylor, N. Pengfei N., B. Derudder, M. Hoyler, J. Huang, F. Witlox (eds.), 17-22. London: Earthscan.

The state of European cities 2016. Cities leading the way to a better future. 2016. European Union. 
Tsenkova Sasha, Zorica Nedovic-Budić. 2006. The urban mosaic of post-socialist Europe. Space, institutions and policy. Physica: Heidelberg.

Turok Ivan, Vlad Mykhnenko. 2008a. "Resurgent European cities?". Urban Research \& Practice (1)1 (March): 54-77.

Turok Ivan, Vlad Mykhnenko. 2008b. "The shifting fortunes of European cities". Town \& Country Planning 77(7/8) (July-August): 319-322.

Turok Ivan, Vlad Mykhnenko. 2007. "The trajectories of European cities, 1960-2005”. Cities 24(3): 165-182.

Van den Berg Leo, Roy Drewett, Leo H. Klaassen, Angelo Rossi, Cornelis H.T. Vijverberg. 1982. Urban Europe. A study of growth and decline. Oxford: Pergamon.

Wallerstein Immanuel. 1979. The capitalist world-economy. Cambridge: Cambridge University Press.

Ward Kevin. 2007. "Creating a personality for downtown. Business improvement districts in Milwaukee". Urban Geography 28(8): 781-808.

World urbanization prospects. The 2014 revision, highlights. 2014. United Nations, Department of Economic and Social Affairs, Population Division. (ST/ESA/SER.A/352). https://esa. un.org/unpd/wup/publications/files/wup2014-highlights.Pdf [dostęp: 30.01.2017]

Andrzej Majer

\section{THE REVIVAL OF MEDIUM CITIES}

Abstract

The changes which took place in cities in the second half of the 20th century and in the 21 st century can be depicted using a scheme of the triad of urbanization, the first part of which is the past urban crisis; the second part - the reaction of social systems to the crisis, i. e. urban renewal; and the third part being the revival of cities. The previously renovated urban centers are gradually being filled with the material fabric of science and culture and places of creative activity for people, who are thus reborn, enriched, and strive to be called "creative". Medium cities are understood here as relatively large urban centers with less than 1 million inhabitants, which takes into account both population and functional criteria.

Empirical indicators indicate a positive trend of "rebirth", which is noticeable in growing populations and in the form of changes in the number, structure, and quality of retail chains, service outlets, and entertainment and gastronomic facilities serving popular culture. In American and European conurbations, which have already undergone "renewal" treatment, the revitalized space and socio-cultural attributes of the new urban environment attract amateurs once again. These tendencies are also beginning to be visible in the post-socialist cities in the countries of Central and Eastern Europe, including Poland.

Keywords: triad of urbanization, revitalization, resurgence of cities 